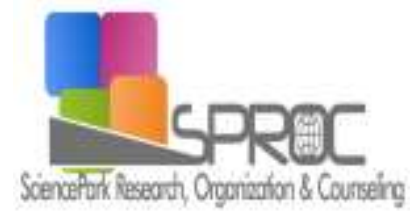

$$
\text { CJES }
$$

http://sproc.org/ojs/index.php/cjes/

\title{
Perceived problem solving skills: As a predictor of prospective teachers' scientific epistemological beliefs
}

Senar Temel*

Suggested Citation:

Cypriot Journal of Educational Science 11

Abstract 
1. Introduction 
1.1. Purpose of the study

2. Method

2.1. Study Group 


\subsection{Data Collection Tool}

\section{Findings}




\section{Conclusion and Discussion}




\section{References}

Ahi Evran Universitesi Kırsehir Egitim Fakultesi Dergisi, 8(1),

Elestirel ve yaratıc dusunme temelli fen ve teknoloji laboratuarı uygulamalarının problem cozme ve yaratıcılık uzerine etkisi.

Uludag Universitesi Egitim Fakultesi Dergisi, XIX(1),

Career World, 29(4)

Educational \& Developmental Psychology, 2

Australian Journal of cozme becerileri.

Sınıf ogretmenligi anabilim dalında okuyan ogretmen adaylarının problem

Bilimsel arastırma yontemler

British Journal of Educational Psychology, 75,

Australian Journal of Teacher Education, 29(1).

Epistemolojik inanclar

Bilimleri ve Uygulama, 4

. Egitim

Lise ogrencilerinin problem cozme becerilerinin bazı degiskenler acısından incelenmesi.

The Conditions of learning. 
Counseling Psychology, 29(6),

Journal of Counseling Psychology, 29(1)

Review of Educational Research, 67(1),

Pamukkale Universitesi Egitim Fakultesi Dergisi, 29(1)

Bilimsel arastırma yontemi: Kavramlar, ilkeler, teknikler

Ilkogretim kurumları (ilkokullar ve ortaokullar) fen bilimleri dersi (3, 4, 5, 6, 7 ve 8. sınıflar) ogretim programı.

Adult cognitive development: Methods and models

International Journal of Science Education, 32(7),

Sciences: Theory \& Practice, 8(3),

Educational

Teaching and Learning, 78

New Directions for

Research in Higher Education, 46(7),

British Journal of Educational Psychology, 78

Elementary Education Online, 9(1),

Science Education, 77(3)

Bilissel-davranıscı terapilerde degerlendirme: sık kullanılan olcekler.

Educational Psychologist, 23

Educational Psychology, 82(3),

Journal of

Journal of Educational Psychology, 84

The Journal of Psychology, 136(1),

the cognitive science society

Tenth annual conference of

Executive control in processes in reading

International, 24(3),

Science Education

Heppner'in problem cozme envanterinin uyarlama, guvenirlik ve gecerlik calısmaları. Yayınlanmamıs yuksek lisans tezi 
Bilimleri Fakultesi Dergisi,45

e-Journal of New World Sciences Academy, 5(3),

Procedia Social and Behavioral Sciences, 2

Hacettepe Universitesi Egitim Fakultesi Dergisi, Special Issue (2), 